by George E. Ericksen, Robert G. Luedke, Robert L. Smith, Robert P. Koeppen, and Fernando Urquidi $B$.

\title{
Peraluminous igneous rocks of the Bolivian tin belt
}

The Bolivian tin belt is unique in the South American Andes because it contains the only known postlower Paleozoic tin deposits and the only known strongly peraluminous silicic igneous rocks there. The authors have studied chiefly the major-and trace-element chemistry and the mineralogy of upper Miocene peraluminous silicic ash-flow tuffs in the Morococala and Los Frailes volcanic fields, located in the central part of the tin belt. These rocks have trace-element concentrations similar to those of the tin-bearing peraluminous granitic plutons of Triassic and middle Tertiary ages in northern Bolivia and the peraluminous ash-flow tuffs of late Tertiary age from Macusani, southern Peru, at the northernmost end of the tin belt.

The Morococala and Los Frailes fields cover a total area of about $10,000 \mathrm{~km}^{2}$ in the most productive part of the tin belt, where the known tin and most other metalliferous deposits are slightly older (early to middle Miocene) than the volcanic rocks. The two fields are attractive exploration target areas for a variety of tin, silver, tungsten, uranium, and base-metal deposits, including both older mineral deposits beneath the volcanic complexes and deposits related to the eruptive centers within the complexes.

\section{Introduction}

A cooperative project by the U.S. Geological Survey and the Servicio Geologico de Bolivia (GEOBOL), partly sponsored and financed by the International Union of Geological Sciences (IUGS), has resulted in the discovery of tin- and lithium-rich peraluminous ash-flow tuffs of late Miocene age in the Morococala and Los Frailes volcanic fields, located in the central part of the Bolivian tin belt (fig. 1). These peraluminous tuffs, together with previously discovered tuffs of similar age and composition at Macusani, southern Peru (Noble and others, 1984; Pichavant, Kontak, Valencia Herrera, and Clark, 1988; Pichavant, Kontak, Briqueu, and others, 1988), occur within the 1,000-km-long tin belt, which extends from northernmost Argentina to southern Peru. Also within this belt are peraluminous granitic plutons of Middle to Late Triassic and late Oligocene to early Mio-

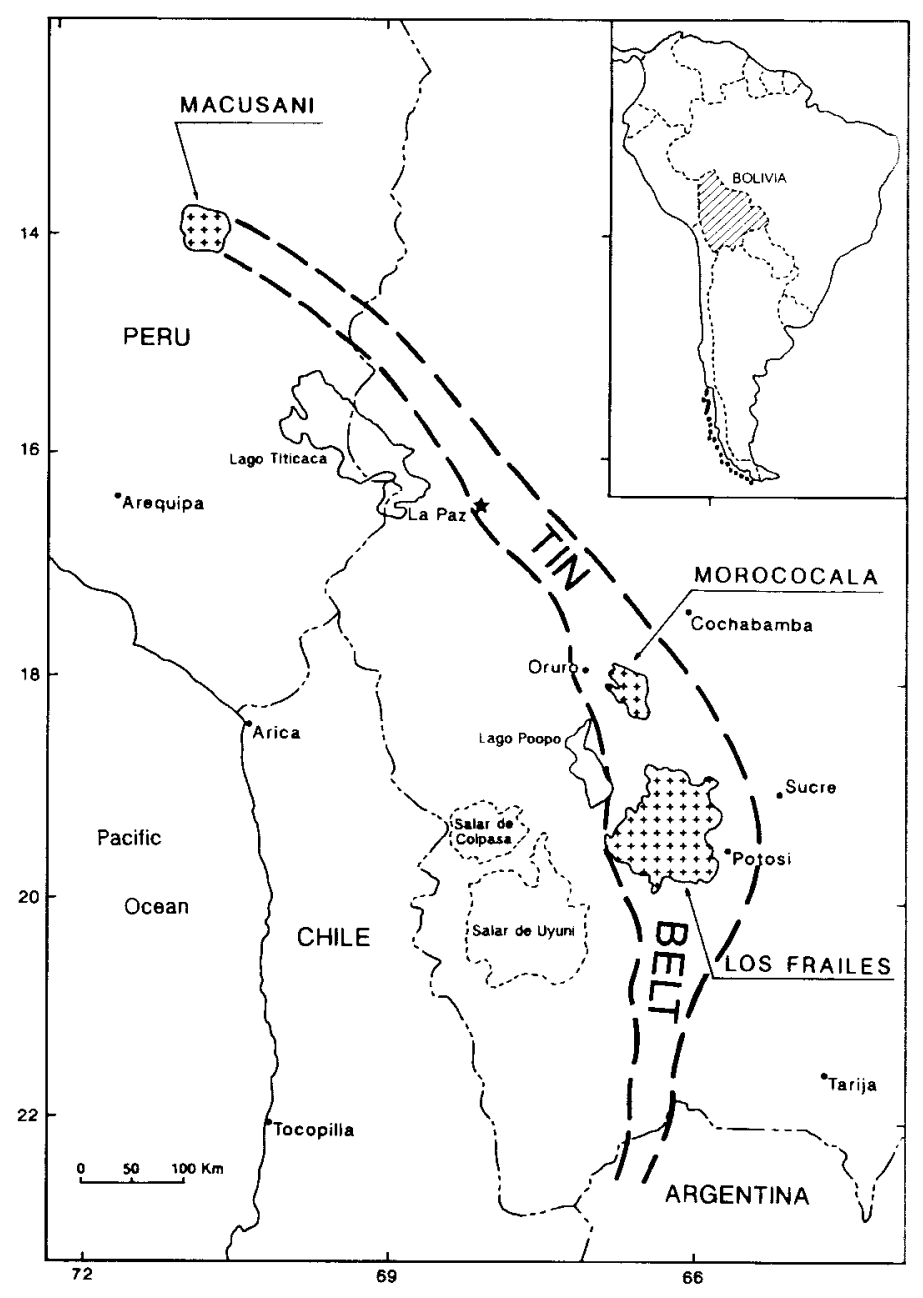

Figure 1.-Location of the Bolivian tin belt and the Macusani, Morococala, and Los Frailes volcanic fields (patterned areas).

cene ages in northern Bolivia (McBride and others. 1983), as well as intensely altered subvolcanic porphyry stocks of Miocene age that extend from central and southern Bolivia into northernmost Argentina (Grant and others, 1980). Tin deposits are related genetically to these plutons and porphyry stocks (Grant and others, 1980; McBride and others, 1983; Sillitoe and others, 1975; Turneaure, 1971). The belt contains the only strongly peraluminous silicic rocks known in the Andes and constitutes one of the great peraluminous igneous complexes of the world.

The volcanic rocks in the Morococala and Los Frailes fields cover an area of about $10.000 \mathrm{~km}^{2}$ in the central and most produc- 
tive part of the tin belt. Major tin deposits of early to middle Miocene age (23-12 Ma (Mega-annum, $10^{6}$ years)) (Grant and others. 1979) occur in areas that are marginal to these fields (figs. 2-4) and in older rocks exposed in windows within the Los Frailes field. Similar tin deposits, as yet undiscovered, may occur in the older rocks beneath the ash-flow tuffs of these fields. In addition, within each of the two voleanic fields are calderas that were the sources of the tuffs and are potential loci of tin deposits associated with heretofore unrecognized or buried intracaldera intrusions. Lead-zinc and tin deposits. for example, occur in the resurgent dome of the Kari Kari caldera (fig. 4), previously considered to be a batholith (Francis and others, 1981) but now known to consist of peraluminous, garnetbearing rhyodacitic to quartz latitic intracaldera ash-flow tuffs of early Miocene age (about $21 \mathrm{Ma}$ ) (Evernden and others, 1977; Grant and others, 1979). Both uranium (A.A. Farfan, unpublished report. 1981: Pardo-Leyton, 1985; Leroy and others, 1985) and wood-tin occurrences are scattered widely in the Los Frailes field. A thermal spring in this field currently is depositing the antimony (Sb) mineral stibnite (fig. 4). Uranium occurrences also have been reported in the Macusani rhyolitic ash-flow tuffs of southern Peru (Valencia and Arroya, 1985) and in rhyolitic tuffs of northwestern Argentina (Stipanicic and others, 1985).

\section{Geologic setting}

The Bolivian tin belt consists mainly of a thick sequence of lower to middle Paleozoic (Ordovician to Devonian) marine clastic sedimentary rocks, structurally deformed and variably metamorphosed, and local inliers of upper Mesozoic red beds and lower Tertiary continental sedimentary and volcanic rocks. These stratified rocks have been intruded by several large granitic plutons in southern Peru and northern Bolivia, as well as by many subvoleanic stocks in southern Peru (Kontak and Clark, 1985), central and southern Bolivia, and northernmost Argentina. The plutons were emplaced during two distinct stages (Clark and Farrar. 1973; Evernden and others, 1977; and McBride and others, 1983), one during the Middle to Late Triassic

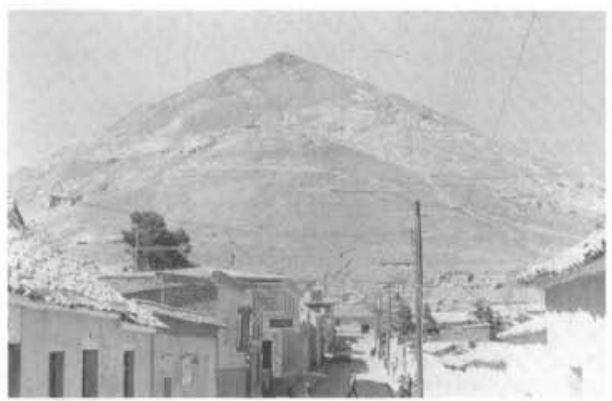

Figure 2.-Cerro Rico de Potosi from a street in the city of Potosi, Bolivia. This conical hill, an eroded porphyry dome near the margin of the Kari Kari caldera, contains many high-grade tin and silver veins that have been mined almost continuously since the mid-16th century. Total production of fine silver from Potosi has been at least 30,000 metric tons, which makes this one of the most productive, if not the most productive, silver deposits in the world.

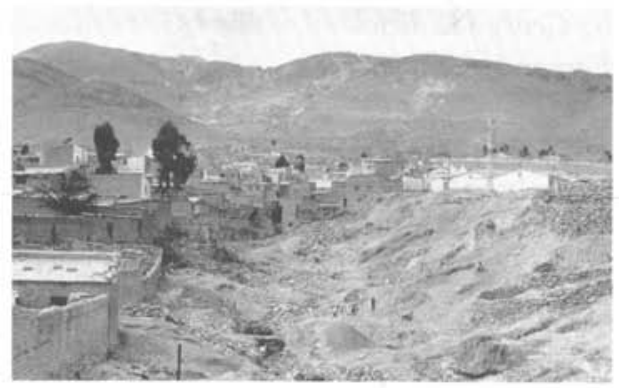

Figure 3. - View over the city of Llallagua, Bolivia, toward tin mines in the hills underlain by the Salvadora stock, the world's largest lode tin deposit. In the foreground are tin-placer operations in one of the major streams that drains the area of the Salvadora stock. This deposit is near the southern margin of the Morococala volcanic field.

(225-202 Ma) and the other during the late Oligocene to early Miocene (26-19 Ma). Porphyry stocks, some of which are peraluminous, and locally coeval volcanic rocks are early to middle Miocene (23-12 Ma) in age (Grant and others, 1979). Ash-flow tuffs in the Morococala field are of late Miocene age (8.5-6.4 Ma; Koeppen and others, 1987). Tuffs of similar age also occur in the Los Frailes field (7.5-7.4 Ma; Evernden and others, 1977). The ash-flow tuffs at Mucusani are middle Miocene to early Pliocene (10.5-4 Ma) in age (Pichavant, Kontak, Valencia Herrera, and Clark. 1988).

\section{Geology and geochemistry of the ash-flow tuffs}

The predominant volcanic rocks in the Morococala and Los Frailes fields are quartz latitic and rhyolitic ash-flow tuffs. These tuffs are generally rich in crystals and contain quartz, biotite, potassic feldspar, and plagioclase phenocrysts in a glassy, but most commonly devitrified, matrix. Mineral assemblages in the more strongly peraluminous rocks include primary muscovite, andalusite, and cordierite. The tuffs contain pumice and xenolithic fragments and show variable degrees of welding. In contrast to the Morococala and Los Frailes tuffs, the Macusani tuffs lack xenolithic material (Pichavant, Kontak. Valencia Herrera, and Clark, 1988).

Each of the several ash-flow tuff units is believed to be related to a distinct caldera center. Three or more such centers are inferred in the Los Frailes volcanic field. We have identified two calderas in the Morococala field, and we infer the presence of a third caldera that overlaps one of them. Some of these centers also contain latestage dacitic to quartz latitic flows, dome-flow complexes, cinder cones, or small stratovolcanoes.

Our investigations of the volcanic rocks in the central Bolivian tin belt, particularly those in the Morococala field, reveal at least three major ash-flow tuff units ranging in age $\left({ }^{40} \mathrm{Ar} /{ }^{39} \mathrm{Ar}\right)$ from 8.4 to $6.5 \mathrm{Ma}$ (Koeppen and others, 1987). From oldest to youngest. these units include (1) andalusite-bearing, two-mica (muscovite and biotite) rhyolitic tuff ( $8.4 \mathrm{Ma}$ ) (fig. 5 ), which is compositionally similar to the tuffs containing muscovite and andalusite at Macusani in 

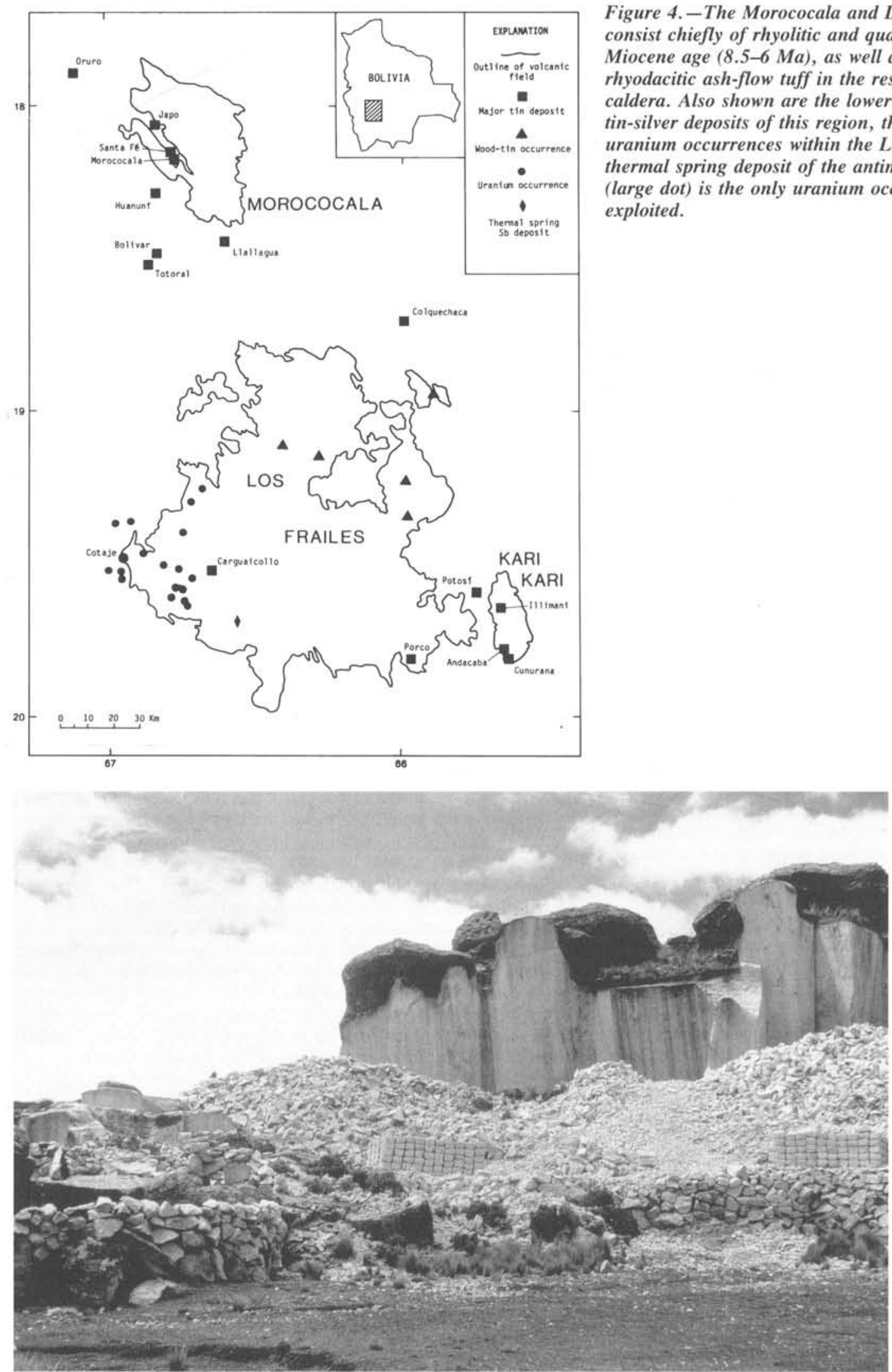

Figure 4.-The Morococala and Los Frailes volcanic fields that consist chiefly of rhyolitic and quartz latitic ash-flow tuffs of late Miocene age (8.5-6 Ma), as well as the lower Miocene (21 Ma) rhyodacitic ash-flow tuff in the resurgent dome of the Kari Kari caldera. Also shown are the lower to middle Miocene major tin and tin-silver deposits of this region, the upper Miocene wood-tin and uranium occurrences within the Los Frailes volcanic field, and the thermal spring deposit of the antimony $(\mathrm{Sb})$ mineral stibnite. Cotaje (large dot) is the only uranium occur-rence that has been exploited.
Figure 5. $-A$ unique stone quarry in columnar jointed, andalusite- bearing,

two-mica rhyolitic ash-flow tuff at the southern edge of the Morococala volcanic field. Hand-cut building blocks of the relatively soft tuff were being produced at the time this photograph was taken in November 1984. 


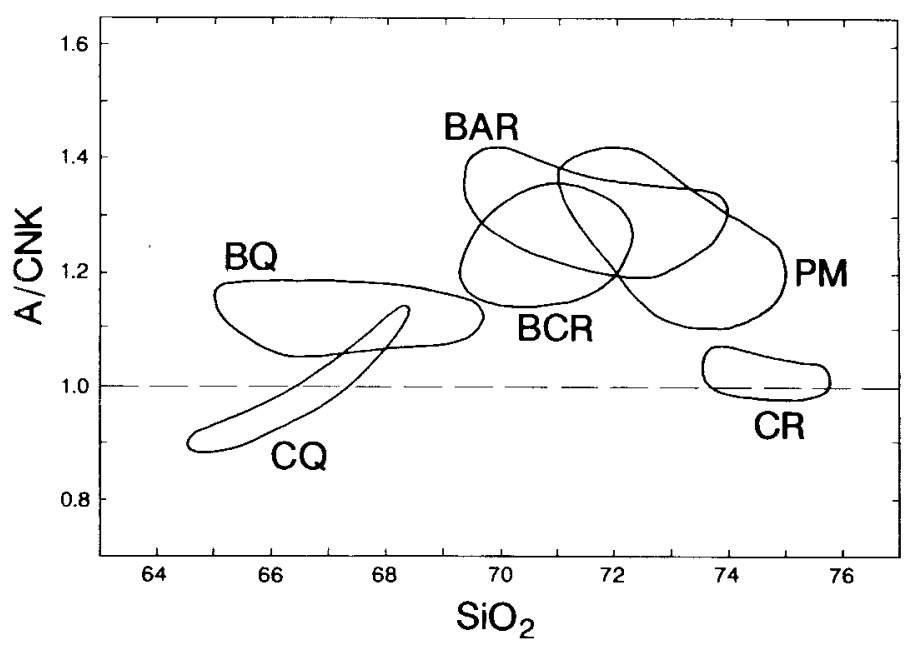

Figure 6.- $\mathrm{A} / \mathrm{CNK}-\mathrm{SiO}_{2}$ diagram showing compositional fields for the following suites of samples of ash-flow tuffs. BAR, Morococala andalusite-bearing rhyolite; $B C R$, Morococala cordierite-bearing rhyolite; $B Q$, Morococala crystal-rich biotite quartz latite; $P M$, Macusani, Peru, andalusite-bearing rhyolite; $C Q$, calc-alkaline quartz latite of northern Chile; and $C R$, calc-alkaline rhyolite of northern Chile. Chemical data for Morococala and northern Chile tuffs are from the study on which this report is based; data for Macusani tuffs are from Noble and others (1984) and from Pichavant, Kontak, Briqueu, and others (1988).

southern Peru (figs. 6, 7); (2) cordierite-bearing biotite rhyolitic tuff $(6.8 \mathrm{Ma})$; and (3) crystal-rich biotite quartz latitic tuff (6.5 Ma). Each of these ash-flow tuffs was erupted from a distinct caldera within the Morococala field: the andalusite- and cordierite-bearing rhyolitic tuffs were erupted sequentially from two overlapping calderas in the south, and the crystal-rich biotite quartz latitic tuff, from a third caldera in the north (Koeppen and others. 1987; Luedke and others, 1990). During the final eruptive phase, quartz latite domes formed in the northern caldera and, locally, at the western margin of the field

Although the three tuff units in the Morococala volcanic field are similar in major- and trace-element chemistry, each unit shows distinctive chemical features. The andalusite-bearing rhyolite, cordierite-bearing rhyolite, and biotite quartz latite average about 72,71 . and 68 weight percent $\mathrm{SiO}_{2}$, respectively. All are high in alkalies and alumina, and normative corundum is greater than 2 percent. The alumina saturation index, $\mathrm{A} / \mathrm{CNK}$, which is the mole ratio $\mathrm{Al}_{2} \mathrm{O}_{3} / \mathrm{CaO}+\mathrm{Na}_{2} \mathrm{O}+\mathrm{K}_{2} \mathrm{O}$ (Shand, 1951), exceeds 1.0 and, for most of these rocks, is $1.1-1.4$.. which indicates that they are moderately to strongly peraluminous. The $\mathrm{A} / \mathrm{CNK}-\mathrm{SiO}_{2}$ compositional fields for these tuffs are compared in figure 6 with the Macusani tuffs of southern Peru and the calc-alkaline tuffs of northern Chile. The andalusite-bearing tuff is the most strongly peraluminous, the crystalrich biotite tuff is the least peraluminous, and the cordierite-bearing uff is intermediate. Selected trace-element concentrations in the three Morococala ash-flow tuff units. the Macusani tuffs, and two Iypes of ash flow tuffs in northern Chile are shown in figure 7. The average tin concentrations are 21 parts per million (ppm) for the andialusite tuff, $12 \mathrm{ppm}$ for the cordierite tuff, and $5 \mathrm{ppm}$ for the crystal-rich biotite tuff. Compared to calc-alkaline quartz latitic and rhyolitic tuffs in northern Chile having similar $\mathrm{SiO}_{2}$ contents, all three Bolivian tuff units are enriched in the elements fluorine $(F)$, boron (B), beryllium (Be), lithium ( $\mathrm{Li}$ ), rubidium $(\mathrm{Rb})$, tin ( $\mathrm{Sn}$ ), uranium $(\mathrm{U})$, and zinc $(\mathrm{Zn})$ and are depleted in chlorine $(\mathrm{Cl})$, hafni-

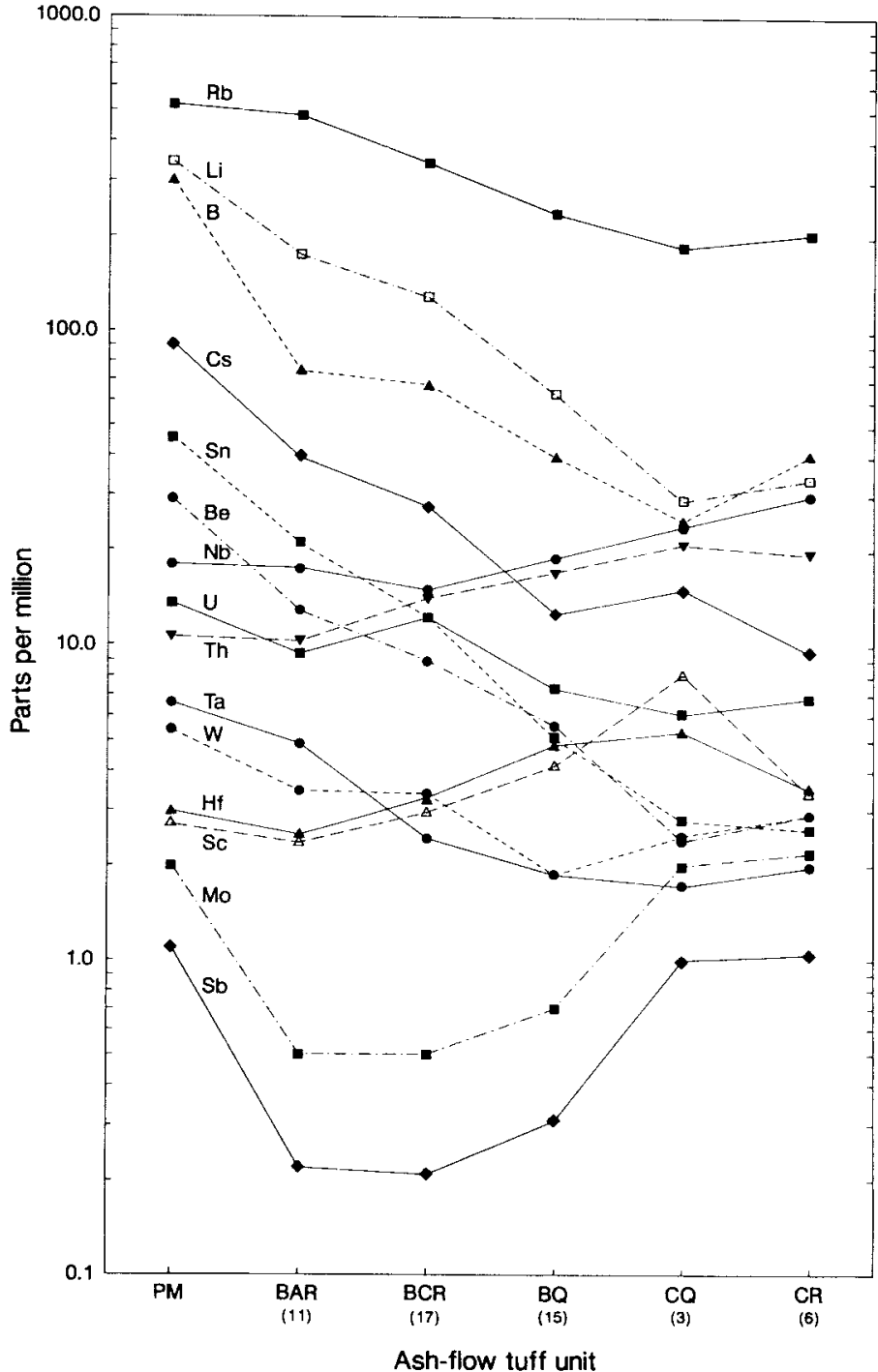

Figure 7.-Average selected trace-element concentrations of suites of samples of ash-flow tuffs shown in figure 6. Numbers of samples used to calculate average values are given in parentheses. Averages for the Macusani tuff are based on analyses reported by Noble and others (1984) and by Pichavant, Kontak, Briqueu, and others (1988), the number of which differs for each element.

um (Hf), molybdenum (Mo), niobium ( $\mathrm{Nb}$ ), antimony (Sb), and thorium (Th). The andalusite- and cordierite-bearing tuffs also are enriched in cesium (Cs), tantalum (Ta), and tungsten (W) but are depleted in zirconium $(\mathrm{Zr})$, whereas the crystal-rich biotite tuff has $\mathrm{Cs}, \mathrm{Ta}$, and $\mathrm{Zr}$ contents that are essentially the same as those of the calc-alkaline tuffs of northern Chile. Nohle and others (1984) and Pichavant, Kontak, Briqueu, and others (1988) reported the Macusani tuffs to be enriched in F, arsenic (As), B, Be, Cs, Li, Nb, phosphorus $(\mathrm{P})$, lead $(\mathrm{Pb}), \mathrm{Rb}, \mathrm{Sb}, \mathrm{Sn}, \mathrm{Ta}, \mathrm{U}, \mathrm{W}$, and $\mathrm{Zn}$ and depleted in $\mathrm{Cl}$, cobalt (Co), chromium (Cr), copper (Cu), Hf, Mo, nickel (Ni), sulfur (S), scandium ( $\mathrm{Sc}$ ), Th, vanadium (V), and yttrium ( $Y$ ) relative to highly silicic tuffs elsewhere. In general, the Macusani tuffs are similar chemically to the andalusite- and cordierite-bearing tuffs in the Morococala volcanic field. 


\section{Discussion}

The major- and trace-element compositions of the peraluminous tuffs, particularly the andalusite- and cordierite-bearing units in the Morococala volcanic field, correspond closely with the compositions of the Macusani tuffs at the northern end of the Bolivian tin belt and with some of the slightly older tin-bearing porphyry stocks in the central and southern part of the tin belt. The granitic plutons in the northern part of the tin belt in Bolivia, although having greater compositional variations, are clearly part of the peraluminous suite that characterizes the igneous rocks of the tin belt. Noble and others (1984) and Pichavant, Kontak. Briqueu, and others (1988) pointed out that the Macusani tuffs are similar compositionally to "S-type" or two-mica granites, and they suggested that the source magmas for these tuffs were generated by partial melting of metapelitic rocks. Stable and radiogenic isotope data cited in these reports and in reports by Tilton (1979) and Schneider (1987) support a predominantly crustal origin for the peraluminous source magmas. However, Lehmann and others (1988) stated that the lower to middle Paleozoic sedimentary host rocks of the tin belt lack anomalous tin values, and they concluded that these rocks were not the source of any significant part of the tin in the mineral deposits.

Although fractionation in the magma chambers may have caused significant chemical changes in the residual magmatic fluids, we doubt that simple melting of heterogeneous pelitic source rocks plus such fractionation could account for all of the unusual trace-element concentrations observed in these Andean peraluminous rocks. The unique association of tin deposits and strongly peraluminous igneous rocks there, relative to the remainder of the great Andean metalliferous province, seems to indicate a unique source of tin-rich magmas. Episodic emplacement of peraluminous igneous rocks and associated tin deposits over a span of about 220 million years also suggests a chemically unique magma source. Such a source might have included tin-bearing crystalline basement rocks similar to those of Precambrian age at Rondônia, Brazil, near the northern border of Bolivia (Ljunggren, 1964; Schneider and Lehmann, 1977) or to those of Precambrian(?) and Paleozoic age in the Sierras Pampeanas of northwestern Argentina (Angelelli and others, 1970; McBride and others, 1976). Schneider (1987) suggested that the magma sources consisted predominantly of upper crustal granulite to amphibolite facies rocks. Our studies have shown that lithic inclusions (restites?) in the ash-flow tuffs of the Morococala volcanic field are granoblastic to gneissic rocks that contain 3.4 to $25 \mathrm{ppm}$ tin. Such rocks may have been the source of the tin.

\section{References}

Angelelli, V., Fernandez Lima, J.C., Herrera, A., and Aristarain, L., 1970. Descripción del mapa metalogénético de la República ArgentinaMinerales metalíferos: Direccion Nacional de Geología y Minería, Anales 15, $172 \mathrm{p}$.

Clark, A.H., and Farrar, E., 1973. The Bolivian tin province: Notes on the available geochronological data: Economic Geology, v. 68, p. 102-106.

Evernden, J.F., Kriz. S.J., and Cherroni M., C., 1977, Potassium-argon ages of some Bolivian rocks: Economic Geology, v. 72, p. 1042-1061.

Francis, P.W., Baker, M.C.W.. and Halls. C.. 1981. The Kari Kari caldera, Bolivia, and the Cerro Rico stock: Journal of Volcanology and Geothermal Research, v. 10, p. 113-124.

Grant, J.N., Halls, C., Avila S., W., and Snelling, N.J., 1979, K-Ar ages of igneous rocks and mineralization in part of the Bolivian tin belt: Economic Geology, v. 74, p. 838-851.

Grant, J.N., Halls, C., Sheppard, S.M.F., and Avila S., W., 1980, Evolution of the porphyry tin deposits of Bolivia, in Ishihara, Shunso, and Takenouchi, Sukune, eds., Granitic magmatism and related mineralization: Mining Geology, Special Issue (Tokyo), no. 8, p $151-173$.
Koeppen, R.P., Smith, R.L., Kunk, M.J., Flores A., M., Luedke, R.G. and Sutter, J.F., 1987, The Morococala volcanics: Highly peraluminous rhyolite ash llow magmatism in the Cordillera Oriental, Bolivia [abs.]: Geological Society of America Abstracts with Programs, v. 19, p. 731

Kontak, D.J., and Clark, A.H., 1985, Exploration criteria for tin and tungsten mineralization in the Cordillera Oriental of southeastern Peru, in Taylor, R.P., and Strong. D.F. eds., Recent advances in the geology of granite-related mineral deposits: The Canadian Institute of Mining and Metallurgy Special Volume 39, p. 157-169.

Lchmann. B., Petersen, U.. Santivanez. R., and Winkelmann. L., 1988. Distribución geoquímica de estaño y boro en la secuencia paleozoica inferior de la Cordillera Real de Bolivia: Sociedad Geológica del Perú Boletín, v. 77, p. 19-27.

Leroy. J., George-Aniel, B., and Pardo-Leyton, E.. 1985, Deposits and radioactive anomalies in the Sevaruyo region (Bolivia). in Uranium deposits in volcanic rocks: International Atomic Energy Agency, Technical Committec Meeting, El Paso, Texas, April 2-5. 1984. Proceedings, p. 289-300.

Ljunggren, P., 1964. The tin deposits of Rondonia, Brazil, as compared with the Bolivian mineralization: Geologiska Föreningens i Stockholm Förhandlingar, v. 85, p. 431-435.

Luedke, R.G., Koeppen, R.P., Flores A., M.. Espinosa O., A., 1990. Reconnaissance geologic map of the Morococala volcanic field, Bolivia: U.S. Geological Survey Miscellaneous Investigations Series Map I-2014. scale $1: 100,000$.

McBride, S.L., Caelles, J.C., Clark, A.H., Farrar, E., 1976, Paleozoic radiometric age provinces in the Andean basement, latitudes $25^{\circ}-30^{\circ} \mathrm{S}$ : Earth and Planetary Science Letters, v. 29. p. 373-383.

Noble, D.C., Vogel, T.A., Peterson, P.S., Landis, G.P., Grant, N.K., Jezek, P.A., and McKee, E.H., 1984, Rare-element enriched, S-type ash-flow tuffs containing phenocrysts of muscovite, andalusite, and sillimanite, southeastern Peru: Geology, v. 12, p. 35-39.

Pardo-Leyton, E., 1985, Uranio en rocas igneas: Intrusivas, sub-efusivas y piroclasticas del origin Andino boliviano, in Uranium deposits in volcanic rocks: International Atomic Energy Agency. Technical Committee Meeting, El Paso. Texas. April 2-5, 1984. Proceedings, p. 255-274.

Pichavant, M., Kontak, D.J. Briqueu, L., Valeneja Herrera, J., and Clark, A.H., 1988, The Miocene-Pliocene Macusani volcanics, SE Peru: II. Geochemistry and origin of a felsic peraluminous magma: Contributions to Mineralogy and Petrology, v. 100, p. 325-338.

Pichavant, M., Kontak, D.J., Valencia Herrera, J., and Clark, A.H., 1988. The Miocene-Pliocene Macusani volcanics, SE Peru: I. Mincralogy and magmatic evolution of a two-mica aluminosilicate-bearing ignimbrite suite: Contributions to Mineralogy and Petrology, v. 100, p. 300-324.

Schneider, A.. 1987, Eruptive processes, mineralization and isotope evolution of the Los Frailes Karikari region, Bolivia: Revista Geologica de Chile. no. 30, p. $27-33$.

Schneider, H.J., and Lehmann, B. 1977. Contribution to a new genetical concept on the Bolivian tin province, in Klemm, D.D., and Schneider, H.J., eds., Time- and strata-bound ore deposits: Berlin, Springer-Verlag. p. $153-168$.

Shand, S.J., 1951. Eruptive rocks (3rd edition): New York, John Wiley, $488 \mathrm{p}$.

Sillitoe, R.H., Halls, C., and Grant. J.N., 1975, Porphyry tin deposits in Bolivia: Economic Geology, v. 70, p. 913-927.

Stipanicic, P., Belluco, A., Nicolli, H.. Gorustovich, S., Salfity, J., Vullier! A., Suriano, J., Koukharski. M., and Abril, E. 1985, Uranium occurrences in the volcanic rocks of northwestern Argentina, in Uranium deposits in volcanic rocks: International Atomic Energy Agency. Technical Committee Meeting. El Paso, Texas, April 2-5, 1984. Proceedings, p. 301-314.

Tilton, G.R., 1979, Isotopic studies of Cenozoic Andean calc-alkaline rocks Carnegie Institution of Washington Year Book 78, p. 298-303.

Turneaure, F.S.. 1971, The Bolivian tin-silver province: Economic Geology v. 66, p. $215-225$.

Valencia, J., and Arroyo, G., 1985. Consideraciones geoquímicas de los indicious uraníferos de Macusani, Puno (Peru), in Uranium deposits in volcanic rocks: Intermational Atomic Energy Agency, Technical Committee Meeting, El Paso, Texas, April 2-5, 1984. Proceedings, p. 275-288. $\square$ 


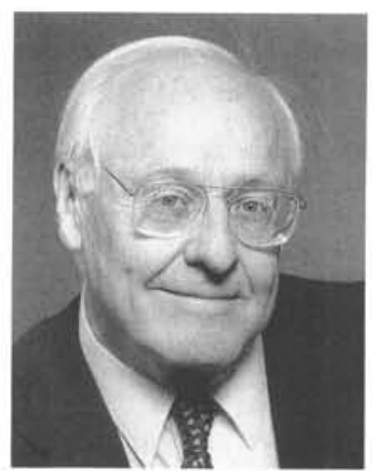

Dr. George E. Ericksen has been a U.S. Geological Survey employee (954 National Center, Reston, VA 22092. USA) for 45 years. Most of his career has concentrated on mineral-resource investigations in South America, particularly in Chile, Peru, and Bolivia. $\mathrm{He}$ has received many honors, including the Bernardo O'Higgins Medal from the Government of Chile, the Distinguished Service Award from the U.S. Department of the Interior, the Richard Owen Award from Indiana University, and the Distinguished Alumnus Award from the University of Montana.

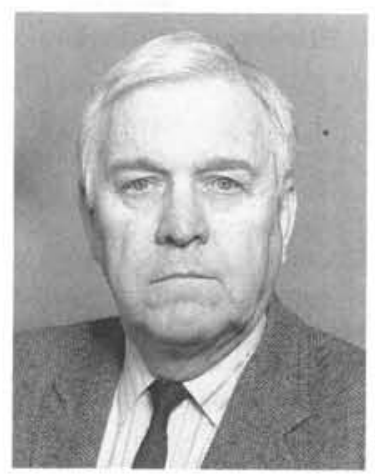

Robert G. Luedke, a Research Geologist with the U.S. Geological Survey (959 National Center, Reston, VA 22092, USA), has conducted field and laboratory studies of base- and precious-metal deposits in sedimentary and igneous environments in the western San Juan Mountains of Colorado. Recently, he has completed studies on potential geothermal and volcanic hazards related to late Cenozoic volcanism in the western conterminous United States, Alaska, and Hawaii. $\mathrm{He}$ is currently modeling and assessing geological, geochemical, and geochronological data on Tertiary volcanic centers in the western United States with respect to mineral deposits related to volcanic centers.

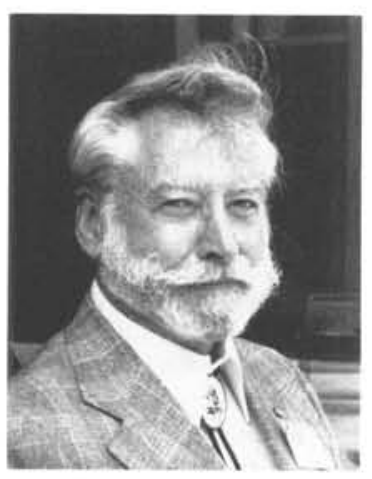

Robert L. Smith is a Senior Research Geologist with the U.S. Geological Survey (2943C Fulton St., Sacramento, CA 95821, USA). He is well known for his seminal research contributions on welded ash-flow tuffs and the evolution of rhyolitic caldera fields in the southwestern United States. His current research concerns the abundance, distribution, and processes controlling trace elements in rhyolitic liquids. He is the recipient of numerous awards including the 1988 Thorarinson Medal of the International Association of Volcanology and Chemistry of the Earth's Interior and an Honorary Doctor of Science degree in 1989 from the University of Lancaster, UK.

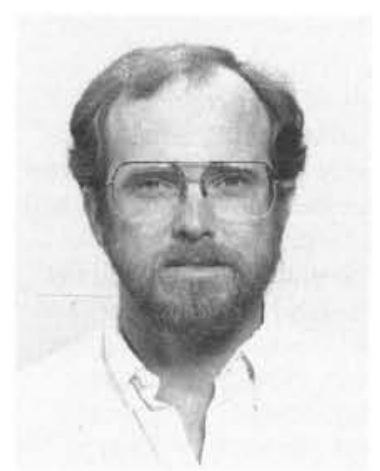

Robert P. Koeppen is a Research Geologist with the U.S. Geological Survey (954 National Center, Reston, VA 22092, USA), where he specializes in the structural and geochemical evolution of silicic volcanoes and their associated mineralization. Currently, his research includes late Cenozoic rhyolite fields in Bolivia and the western United States, as well as Precambrian rhyolites in the southeastern Piedmont province of the United States.

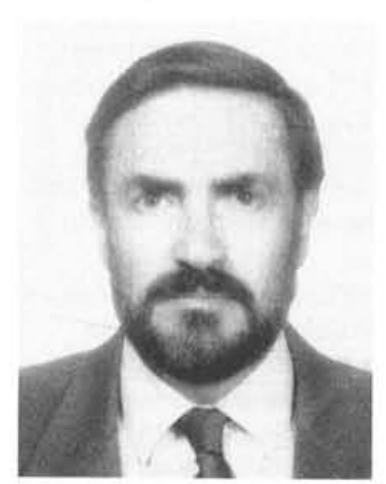

Fernando Urquidi-Barrau is a Mineral Economist in the American Embassy in La Paz, Bolivia. He holds a bachelor's degree in geological engineering and master's degree in business administration from the Universidad Mayor de San Andres, La Paz, as well as a doctorate from the Imperial College of Science and Technology, University of London, England. 